\title{
Article \\ Effect of Copper Nanoparticles and Ions on Epididymis and Spermatozoa Viability of Chinese Soft-Shelled Turtles Pelodiscus sinensis
}

\author{
Li Yang ${ }^{1,2,3}$, Yating Wei ${ }^{1,3}$, Shuai Gao ${ }^{4}$, Qifei Wang ${ }^{1,3}$, Jiaqi Chen ${ }^{4}$, Boping Tang ${ }^{1,2,3, *}$ and Xunguang Bian ${ }^{1,4, *}$ \\ 1 Jiangsu Provincial Key Laboratory of Coastal Wetland Bioresources and Environmental Protection, \\ Yancheng 224007, China; yangli86716@163.com (L.Y.); ttzdsys@yctu.edu.cn (Y.W.); \\ huabzhang@163.com (Q.W.) \\ 2 Jiangsu Synthetic Innovation Center for Coastal Bioagriculture, Yancheng 224007, China \\ 3 School of Wetlands, Yancheng Teachers University, Yancheng 224007, China \\ 4 College of Ocean and Biology Engineering, Yancheng Teachers University, Yancheng 224007, China; \\ ahgebaoming@163.com (S.G.); jlcbe@126.com (J.C.) \\ * Correspondence: tangbp@yctu.edu.cn (B.T.); bxguang8311@163.com (X.B.)
}

check for updates

Citation: Yang, L.; Wei, Y.; Gao, S.; Wang, Q.; Chen, J.; Tang, B.; Bian, X. Effect of Copper Nanoparticles and Ions on Epididymis and Spermatozoa Viability of Chinese Soft-Shelled Turtles Pelodiscus sinensis. Coatings 2022, 12, 110. https://doi.org/ $10.3390 /$ coatings12020110

Academic Editor: Ajay Vikram Singh

Received: 17 December 2021

Accepted: 15 January 2022

Published: 19 January 2022

Publisher's Note: MDPI stays neutral with regard to jurisdictional claims in published maps and institutional affiliations.

Copyright: () 2022 by the authors. Licensee MDPI, Basel, Switzerland. This article is an open access article distributed under the terms and conditions of the Creative Commons Attribution (CC BY) license (https:// creativecommons.org/licenses/by/ $4.0 /)$.

\begin{abstract}
Copper nanoparticles (CuNPs) have been widely used in various industrial and commercial applications, which become a potential threat to aquatic organisms. Nevertheless, their potential toxicity to the epididymis and sperm remains little known. In this study, we evaluated the effect of $\mathrm{CuNPs}$ and copper ions $\left(\mathrm{CuSO}_{4}\right)$ on the spermatozoa viability, epididymal structure, antioxidant enzyme activity, and inflammatory cytokines in cauda epididymis of the Chinese soft-shelled turtle. Results showed that the spermatozoa viability of Chinese soft-shelled turtles decreased significantly with an increase in CuNPs or $\mathrm{Cu}$ ions concentrations. The epithelial cells of the epididymal duct of the Chinese soft-shelled turtles with the treatment of $5 \mathrm{mg} \mathrm{kg}^{-1} \mathrm{CuNPs}$ were slightly swollen, and the connective tissue between the epididymal ducts was loose. The epithelial structure of the epididymal tube was severely damaged with an increase in $\mathrm{Cu}$ ion concentrations. Compared to the control, the antioxidative enzymes activities and the expression of IL- $1 \beta$, TNF- $\alpha$, and IL- 6 mRNA in the epididymis significantly increased with the treatment of $\mathrm{CuNPs}$ or $\mathrm{CuSO}_{4}$. The present study revealed that $\mathrm{Cu}$ ions exert more harmful effect on the epididymis and spermatozoa viability of Chinese soft-shelled turtles than copper nanoparticles.
\end{abstract}

Keywords: CuNPs; epididymis; sperm; Chinese soft-shelled turtles; toxicity

\section{Introduction}

Copper nanoparticles (CuNPs) are one of the most commonly used nanomaterials, which have received much attention in these years and have been widely used in fungicides, cosmetics, printers, and electronics, because of their antifungal, optical, and electrical properties [1,2]. The extensive use of CuNPs has led to direct contamination in the aquatic environment, as they can be released into aquatic ecosystems through indirect pathways, such as runoffs and leaching from industrial and agricultural sites, and also through direct pathways, with the use of antifouling paints [3,4], raising a global concern for ecological impacts of such contamination [5]. The aquatic environment is considered to be a sink for pollutants [6]. Although copper is an essential trace metal required by all living organisms, it can be toxic to organisms when it excesses the physiological requirement of organisms. The application of CuNPs has caused adverse effects on aquatic organisms, such as fish, daphnias, and algaes, due to their dynamic physicochemical processes in an aquatic environment $[7,8]$. The $\mathrm{LC}_{50}$ value represents a common point in the lethal physiological response to toxicity, which has been abundant in data in many crustaceans. For example, the 96 h-LC 50 value for shrimps of Exopalaemon carinicauda, Echinogammars olivii, Sphaeroma serratum, and Palaemon elegans was $0.712 \mathrm{mg} \mathrm{Cu} / \mathrm{L}, 0.25 \mathrm{mg} \mathrm{Cu} / \mathrm{L}, 1.98 \mathrm{mg} \mathrm{Cu} / \mathrm{L}$, and $2.52 \mathrm{mg} \mathrm{Cu} / \mathrm{L}$, 
respectively $[9,10]$. In addition, for paddy field crab Paratelphusa hydrodromus and freshwater crab, Barytelphusa cunicularis, the $96 \mathrm{~h}-\mathrm{LC}_{50}$ values recorded were $15.70 \mathrm{mg} \mathrm{Cu} / \mathrm{L}$ and $215 \mathrm{mg} \mathrm{Cu} / \mathrm{L}$, respectively [11,12]. Likewise, in freshwater crayfish, Procambarus clarkia, the $96 \mathrm{~h}-\mathrm{LC}_{50}$ value reached $162 \mathrm{mg} \mathrm{Cu} / \mathrm{L}$ [13]. These large variations in sub-lethal effects to $\mathrm{Cu}$ toxicity in crustaceans appear to be species specific. There are a large number of studies on the effects of copper on fish toxicity. According to a review by Malhotra et al. [14], it can be seen that the acute and sub-chronic exposure concentrations of different fish to copper vary significantly, ranging from micrograms to approximately $250 \mathrm{~g}$ per liter.

The negative impacts of CuNPs on different aquatic organisms have been reported by many researchers; however, it remains difficult to conclude what is the major cause of NPs toxicity [15]. Most studies showed that the toxicity of metal nanoparticles (MNPs) to organisms was attributed to their release of soluble ions $[7,16,17]$, while some other studies demonstrated that CuNPs could penetrate into cells or move to different organs and tissues, thus damaging the organisms $[18,19]$. There are also some reports indicating that the toxicity of CuNPs was caused by the combination of nanoparticles and the released copper ions [2,20]. Zhang et al. [21] illustrated that the toxicity of CuNPs to zebrafish embryonic cells was not only caused by the released $\mathrm{Cu}$ ions, and $\mathrm{CuNPs}$ and $\mathrm{Cu}$ ions accounted for $48.4 \%$ and $51.6 \%$ of the total Cu content, respectively.

Sperm quality analysis is considered to be a potential tool for use in the assessment of environmental quality and has been successfully applied as a biomarker to evaluate the effects of contaminants in the aquatic environment on fish reproduction $[22,23]$. Contaminants in aquatic environments could affect the fertilization efficiency of aquatic organisms [24], which can decrease spermatozoa motility and fertilization efficiency. Histopathological studies can be used as a dependable tool to investigate the toxic effects of environmental pollutants and to assess symptoms of damages [25]. Gürkan et al. [26] reported that 10 days of $\mathrm{Fe}_{2} \mathrm{O}_{3}$ NPs exposure caused significant histopathological damages to rainbow trout (Oncorhynchus mykiss). Antioxidant enzymes are known to be the first line of response upon stress, playing an important role in maintaining normal metabolism and function of the organisms [27]; they play an important role in maintaining the ROS homeostasis of organisms [28]. The classic antioxidant enzymes include superoxide dismutase (SOD), catalase (CAT), glutathione peroxidase (GPx), etc. They are very sensitive to environmental pollutants, and thus, they are usually employed as important biomarkers in numerous environmental toxicology experiments $[29,30]$.

Previous studies suggested that contaminants could cause a potential risk to the fish species during their reproduction season when fertilization occurs [31]. Research on the effect of contamination on fish spermatozoa has mainly focused on the influence of the ionic form of metals. Few studies have performed risk assessment of toxicity of nanomaterials to male gamete motility. $\mathrm{CuSO}_{4}, \mathrm{CuNPs}$, and $\mathrm{CuO}$ NPs in the aqueous environment primarily cause a reduction of spermatozoa velocity, and the effect of $\mathrm{Cu}$ ions on sea trout spermatozoa motility was more harmful than that of copper nanoparticles [24]. Our current understanding of the toxic of CuNPs to the sperm in reptiles is severely limited as compared to the fish. Chinese soft-shelled turtles (Pelodiscus sinensis) are one of the common species of reptiles and are widely distributed in China, which is famous for their economic and pharmacologic value. Freshwater turtles play a major role in maintaining balance in the ecosystem of any wetland. They act as scavengers by decaying dead organic matter and indicators of a healthy aquatic ecosystem. Some of them are carrion eating species that feed on aquatic weeds and reduce eutrophication. As a representative of freshwater turtles, Chinese soft-shelled turtles first appeared 120 million years ago and have an important position in the study of species evolution. Our previous results have shown that the epididymis of the Chinese soft-shelled turtle is similar to that of mammals and is divided into three parts: caput, corpus, and cauda. The cauda epididymis is the main site of sperm storage [32]. The Chinese turtles' epididymis is unique in that sperm can be stored in its epididymis long-term with a low apoptosis rate. It can be seen that the epididymis plays an important role in the storage of sperm and the reproduction of species. 
In this study, we aimed to assess the in vivo effects of CuNPs and $\mathrm{CuSO}_{4}$ on spermatozoa viability, epididymal structure, antioxidant enzyme activity, and inflammatory cytokines in cauda epididymis of the Chinese soft-shelled turtle. This study may provide preliminary information regarding the ecological impacts of CuNPs on the fertilization efficiency of aquatic organisms.

\section{Materials and Methods}

\subsection{Chemicals and the Test Organism}

CuNPs with a primary size of $40 \mathrm{~nm}$ were purchased from Sigma (St. Louis, MO, USA), the particle size was determined using Transmission Electron Microscopy (TEM, JEOL Ltd., Tokyo, Japan), and the pristine shape of CuNPs used in the experiment was spherical (Supplementary Materials). The stock suspension of CuNPs $\left(100 \mathrm{mg} \mathrm{L}^{-1}\right)$ was prepared by suspending the powder in MilliQ water. The suspension was sonicated $(20 \mathrm{kHz}, 100 \mathrm{w}$, $20 \%$ cycle off at $25^{\circ} \mathrm{C}$ ) in an ice-cold bath for at least $40 \mathrm{~min}$ and stirred for $30 \mathrm{~min}$. Cu ions stock solution ( $100 \mathrm{mg} \mathrm{L}^{-1}$ ) was prepared by dissolving $\mathrm{CuSO}_{4}$ (99\% purity, Sigma-Aldrich) in deionized water. The concentration of the products tested (CuNPs and $\mathrm{CuSO}_{4}$ ) was expressed as $\mathrm{mg} \mathrm{Cu} \mathrm{L}^{-1}$ in the media regardless of the dissolution and aggregation of the products.

A total of 45 adult male Chinese soft-shelled turtles (body weight $700 \pm 50 \mathrm{~g}$ ) were chosen as model species of aquatic organism, which were purchased from Yancheng, Jiangsu Province, China. The healthy individuals with basically the same size, having no damage on the body surface and showing normal activities, were selected in the experiment. Animals were treated in accordance with the Care and Use of Wild Animals in The People's Republic of China. In the laboratory, turtles were reared in big water tanks $(30 \times 40 \times 40-\mathrm{cm})$ containing sand and filled with freshwater during the 2021 breeding season for 7 days prior to the beginning of experiments.

Turtles were divided into five groups (Control, $5 \mathrm{mg} \mathrm{kg}^{-1}$, and $50 \mathrm{mg} \mathrm{kg}^{-1} \mathrm{CuNPs}$ or $\mathrm{CuSO}_{4}$ ), and each treatment had three replicates. We calculated the volume of the required stock solution based on the body weight of the turtle; then, we set the volume to $20 \mathrm{~mL}$ and injected it into the abdominal cavity of the turtle. The control group was replaced with PBS (sterilized distilled water) solution. The animals were sacrificed by cervical dislocation at 24,48 , and $72 \mathrm{~h}$ after intraperitoneal injection. The cauda epididymis was separated according to the anatomical structure. One of each pair of cauda epididymis was used for light microscopy; the other was used to collect sperm to test its viability. Subsequently, the cauda epididymis with sperm removed was cryopreserved in liquid nitrogen for other experiments.

\subsection{Light Microscopy}

The samples were fixed in neutral buffered formalin, embedded in paraffin, and serial sectioned (at $5 \mu \mathrm{m}$ ). These sections were stained with Harris' hematoxylin and eosin (HE) for light microscopic observation. Slides were assessed using an Olympus microscope (BX53, Olympus Corporation, Tokyo, Japan), camera (Olympus DP73, Olympus Corporation, Tokyo, Japan), and the AnalySIS image-analyzing system (AnalySIS).

To observe the integrity of the epididymal epithelial structure, 20 pictures of straight perpendicularly cut epithelium sections were taken at $400 \times$ magnification. In each picture, the epithelium was measured 3 times.

\subsection{Epididymal Sperm Preparation and Viability Test}

The epididymal sample was placed in phosphate-buffered saline and exsanguinated for 5-10 min. After transferring to fresh PBS, the connective tissue around the epididymis was removed, and the sperm in the epididymal tubules flew into PBS for 10-15 min to ensure that all sperm are obtained as much as possible. Then, we transferred the PBS buffer containing sperm to a centrifuge tube and concentrated it by centrifugation at $700 \times g$ for 
10 min at $4{ }^{\circ} \mathrm{C}$. Sperm were suspended in sterile PBS. We diluted the sperm concentration to $10^{6} \mathrm{~mL}^{-1}$.

Sperm viability was quantified with double staining of fluorescein isothiocyanate (FITC) conjugated annexin-V and propidium iodide (PI) (Biouniquer, BU-AP0103, Biouniquer Technology, Nanjing, China). Ten thousand cells per sample were acquired with an FACS scan flow cytometer (FACScan, Becton Dickinson, Franklin Lakes, NJ, USA). Take $1 \mathrm{~mL}$ of the prepared sperm suspension, which was washed twice with binding buffer and processed following the manufacturer's instructions. Cells fluorescence was analyzed with flow cytometry using the Cell Quest Pro software (Beckman Coulter, Becton Dickinson, Franklin Lakes, NJ, USA).

\subsection{Biochemical Assay}

The epididymal tube sample from which the sperm has been removed was homogenized with a glass homogenizer in ice-cold conditions by adding Tris- $\mathrm{HCl}$ buffer and a small amount of protease inhibitor. Then, homogenates were centrifuged at $9000 \times g$ for $30 \mathrm{~min}$ at $4{ }^{\circ} \mathrm{C}$. The supernatant was collected for measuring oxidative stress markers. SOD, $\mathrm{CAT}$, and GSH activities were determined using the kits (Nanjing Jiancheng Bioengineering Institute, Nanjing, China) and according to the manufacturer's instructions.

\subsection{Analysis of mRNA Expression Levels}

Primers were designed using Primer 3 software (http:/ / bioinfo.ut.ee/primer3/, accessed on 19 February 2021). The expression of IL-1 $\beta$, TNF- $\alpha$, and IL-6 mRNA in the cauda epididymis of $\mathrm{Cu}$-treated soft-shelled turtles was examined using real-time PCR. Total RNA was isolated from tissue samples using the RNeasy Mini Kit Qiagen (Catalog no. 74104).

Real-time reverse transcription polymerase chain reaction (RT-PCR) was used to detect the mRNA expression levels of IL- $1 \beta$, TNF- $\alpha$, and IL- 6 . Total RNAs were extracted from epididymal epithelial cells by adding $1 \mathrm{~mL}$ of TRIzol Reagent (Invitrogen, Waltham, CA, USA) and reverse-transcribed to form cDNAs using the ABI7500 Real-Time PCR system (Applied Biosystems, Foster City, CA, USA) according to the manufacturer's instructions. $\beta$-actin was used as an endogenous quantity control. The primer sequences used in the quantitative real-time PCR reactions were as shown in Table 1 . The total volume of $20 \mu \mathrm{L}$ PCR reactions was prepared by mixing $1.0 \mu \mathrm{L}$ of cDNA sample, $10.0 \mu \mathrm{L}$ of $2 \times$ SYBR Premix Ex Taq II (Tli RNaseH Plus, Takara Bio Inc., Shiga, Japan), 0.4 L of forward primer (10 M), $0.4 \mathrm{~L}$ of reverse primer $(10 \mathrm{M})$, and $8.2 \mu \mathrm{L}$ of $\mathrm{ddH}_{2} \mathrm{O}$. The final results were presented as the ratios of the relative amount of the target gene to the control gene using the $2^{-\Delta \Delta \mathrm{CT}}$ equation, where $\Delta \Delta \mathrm{CT}=\mathrm{CT}$ (target gene) $-\mathrm{CT}$ (internal control gene). The results were analyzed using the Rotor-Gene 6.0 software (Corbett Research, Mortlake, Australia). The results were comparable to those normalized to $\beta$-actin, and the statistical analysis was performed using the average relative mRNA levels from three independent samples.

Table 1. Primers and annealing temperature for real-time PCR.

\begin{tabular}{|c|c|c|c|}
\hline Genes Primer Sequence $\left(5^{\prime}-3^{\prime}\right)$ & $\begin{array}{c}\text { Annealing } \\
\left({ }^{\circ} \mathrm{C}\right)\end{array}$ & $\begin{array}{l}\text { Length } \\
\text { (bp) }\end{array}$ & $\begin{array}{c}\text { GenBank } \\
\text { Accession Number }\end{array}$ \\
\hline $\begin{array}{l}\text { psIL-1 } \beta \text { Fwd GACAATGACTTGAGCAGCA } \\
\text { psIL-1 } \beta \text { Rev AGCCATGTTCAGCCTCACTT }\end{array}$ & 60 & 226 & JX846915 \\
\hline $\begin{array}{l}\text { psTNF- } \alpha \text { Fwd CAGAGAGCAGGCCCTATGAC } \\
\text { psTNF- } \alpha \text { Rev TTGTTCCCCTTGAAGACCAC }\end{array}$ & 60 & 218 & XM_006127997 \\
\hline $\begin{array}{l}\text { psIL-6 Fwd GGAGATGCTTGCCCAAAAT } \\
\text { psIL-6 Rev TGCACCAGGATTTTTCACC }\end{array}$ & 60 & 244 & XM_006138351 \\
\hline $\begin{array}{c}\beta \text {-actin-Fwd TGTTACCCATACTGTGCCCATC } \beta \text {-actin-Rev } \\
\text { TAGCCATCTCCTGTTCAAAATCC }\end{array}$ & 60 & 212 & EU727174 \\
\hline
\end{tabular}




\subsection{Statistical Analysis}

All data were expressed as means \pm SE. Significant differences were analyzed by oneway ANOVA followed by Tukey's test using SPSS (version 19.0). $p<0.05$ was considered significant.

\section{Results and Discussion}

The widespread use of CuNPs inevitably results in their release into the aquatic environments; therefore, it is essential to evaluate their potential toxic effects on aquatic organisms. In our study, the response of the Chinese turtle to the external stimulus has gradually deteriorated, and the degree of injury was positively correlated with the increase in $\mathrm{Cu}$ concentration and time. At $50 \mathrm{mg} \mathrm{kg}^{-1}$, although the animals still survive, their physiological state has been very poor; there was almost no response to external stimuli, as the head and neck remained outside with the treatment of $50 \mathrm{mg} \mathrm{kg}^{-1} \mathrm{CuSO}_{4}$ for $72 \mathrm{~h}$. In addition, there were no changes in the weight and color of the turtles with the treatment of $\mathrm{CuSO}_{4}$ or $\mathrm{CuNPs}$ for $72 \mathrm{~h}$.

\subsection{Effect of CuNPs and $\mathrm{Cu}$ Ions on Sperm Viability}

Sperm analysis is considered to be useful for determination of the male infertility cause [33]. Some reports showed that $\mathrm{Cu}$ can negatively affect sperm quality parameters in rats [34] and rabbits [35] under acute exposure. In the present study, sperm viability was detected by the flow cytometry. Results showed that the treatment of CuNPs and $\mathrm{CuSO}_{4}$ resulted in a dramatic decrease in sperm viability after $24 \mathrm{~h}$ of injection compared with the control (Figure 1B-E). The sperm viability of Chinese soft-shelled turtles decreased significantly with a further increase in CuNPs or $\mathrm{Cu}$ ion concentrations (Figure 1F). Sperm viability was nearly $18.2 \%$ and $40.4 \%$ for 50 and $5 \mathrm{mg} \mathrm{kg}^{-1} \mathrm{CuSO}_{4}$ after $72 \mathrm{~h}$, respectively. Meanwhile, the viability was much higher with the treatment of 50 and $5 \mathrm{mg} \mathrm{kg}^{-1} \mathrm{CuNPs}$ (Figure $1 \mathrm{~F}$ ), suggesting that $\mathrm{Cu}$ ions were more toxic to the sperm. The amount of soluble ions released from CuNPs is much lower than the concentration of corresponding $\mathrm{CuSO}_{4}$. The toxicity of copper ions on the organisms was much higher than that of the nanoparticles, although nanoparticles could cause toxicity to the organisms. Kowalska-Góralska et al. [24] reported that $\mathrm{CuNPs}$ and $\mathrm{CuO}$ NPs exerted less harmful effects than $\mathrm{Cu}$ ions on spermatozoa motility of sea trout. In line with this, Adam et al. [16] illustrated that the toxicity of $\mathrm{CuO}$ NPs to aquatic organisms was mainly caused by the released $\mathrm{Cu}$ ion.

\subsection{Effect of $\mathrm{CuNPs}$ and $\mathrm{Cu}$ Ions on the Histological Analysis}

Compared with the control, the epithelial cells of the epididymal duct of the Chinese soft-shelled turtle with the treatment of $5 \mathrm{mg} \mathrm{kg}^{-1} \mathrm{CuNPs}$ were slightly swollen, and the connective tissue between the epididymal ducts was slightly loose (Figure 2A); meanwhile, we found intravascular congestion, and a small amount of blood appeared in the lumen blood cells in the epididymis of Chinese soft-shelled turtle with the treatment of $50 \mathrm{mg} \mathrm{kg}^{-1}$ CuNPs; however, the overall structure of the epididymal duct is basically intact (Figure 2B). Part of the epithelium of the epididymal tube was peeled off, and the connective tissue between the epididymal tubes was very loose in the epididymis with the treatment of $5 \mathrm{mg} \mathrm{kg}^{-1} \mathrm{CuSO}_{4}$ (Figure 2C,D). The epithelial structure of the epididymal tube was severely damaged with an increase in Cu ion concentrations (from 5 to $50 \mathrm{mg} \mathrm{kg}^{-1}$ ), cell connections were broken, and sperm in the cavity may flow to the knot tissue through the rupture (Figure 2E). 


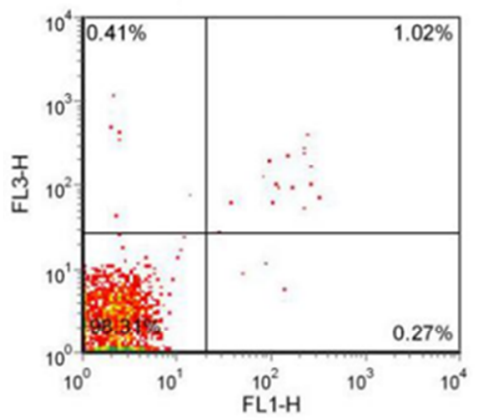

(A)

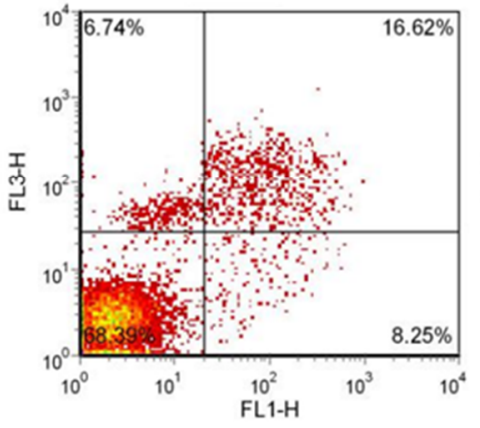

(D)

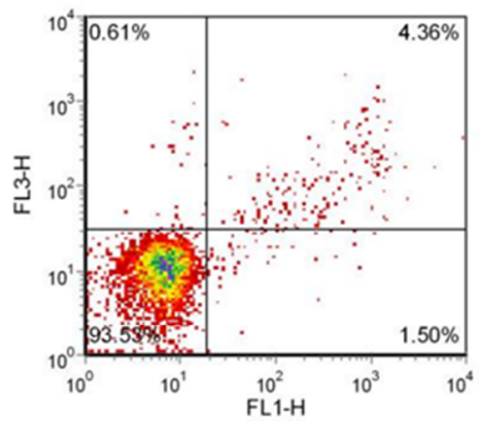

(B)

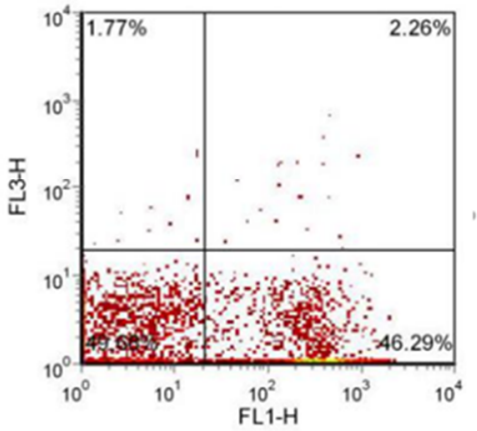

(E)

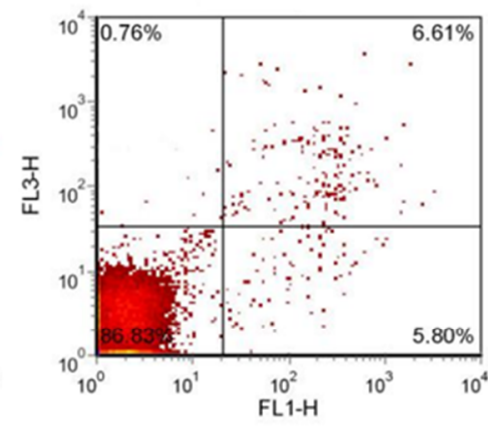

(C)

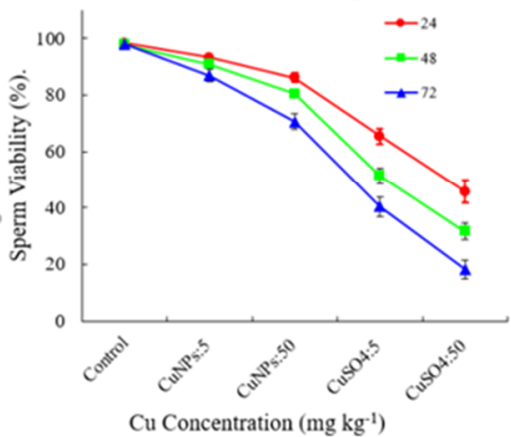

(F)

Figure 1. Flow cytometry analysis using Annexin $\mathrm{V}$ and propidium iodide (PI) staining illustrating sperm viability at $24 \mathrm{~h}$. Note: (A) Control; (B) CuNPs $5 \mathrm{mg} \mathrm{kg}^{-1}$; (C) CuNPs $50 \mathrm{mg} \mathrm{kg}^{-1}$; (D) $\mathrm{CuSO}_{4}$ $5 \mathrm{mg} \mathrm{kg}^{-1}$; (E) $\mathrm{CuSO}_{4} 50 \mathrm{mg} \mathrm{kg}^{-1}$; (F) sperm viability.

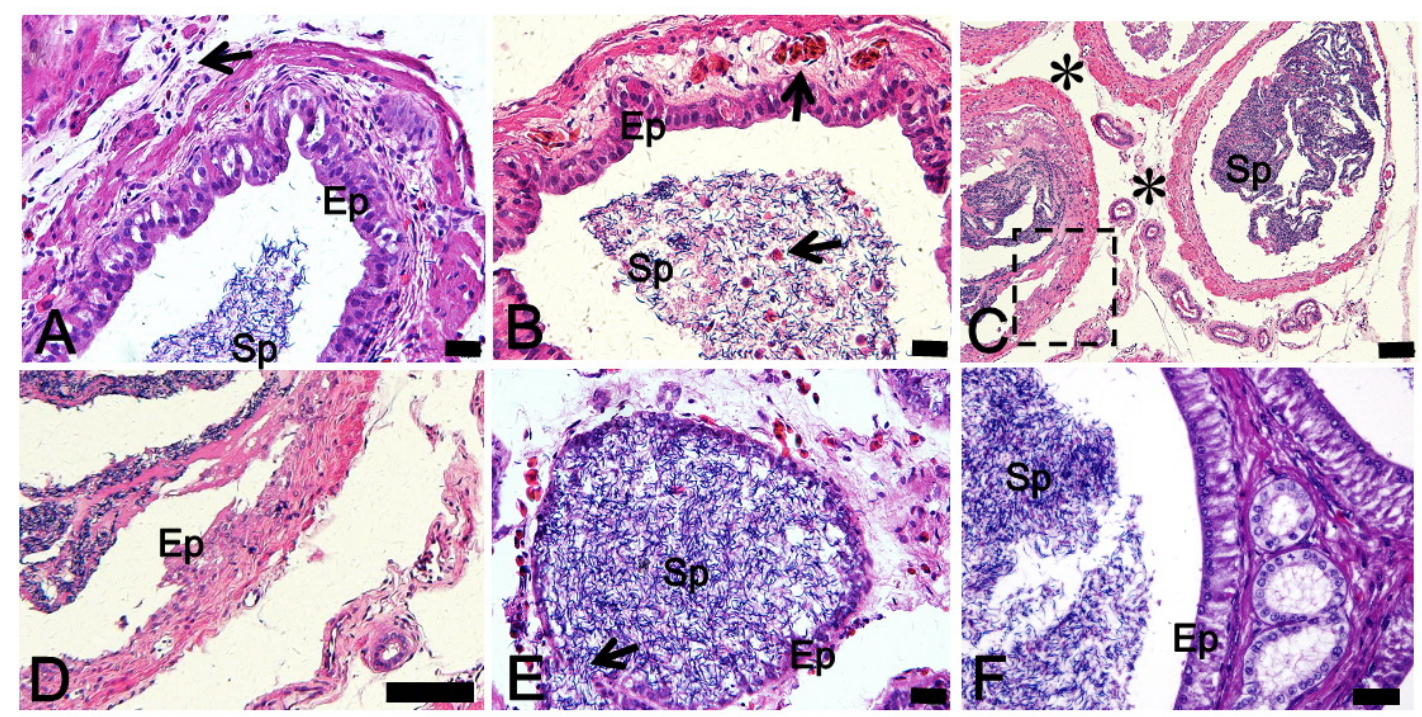

Figure 2. Photomicrograph of cauda epididymis in Chinese soft-shelled turtle with different treatment. Note: (A) Control; (A) CuNPs $5 \mathrm{mg} \mathrm{kg}^{-1}$; (B) CuNPs $50 \mathrm{mg} \mathrm{kg}^{-1}$; (C) $\mathrm{CuSO}_{4} 5 \mathrm{mg} \mathrm{kg}^{-1}$; (D) Higher magnification of the boxed area in (C); (E) $\mathrm{CuSO}_{4} 50 \mathrm{mg} \mathrm{kg}^{-1}$; (F) Control. The arrow in (A) shows connective tissue, the arrow in (B) shows blood cells, the asterisk in $\mathrm{C}$ also shows connective tissue, and the arrow in (E) shows sperm outflow. Ep, epithelium; Sp, Sperm. Scale bar: $(\mathbf{A}, \mathbf{B}, \mathbf{E})=20 \mu \mathrm{m}$; $(\mathbf{C}, \mathbf{D})=100 \mu \mathrm{m} ;(\mathbf{F})=50 \mu \mathrm{m}$.

The plasma membrane is an important structure for maintaining a highly controlled intracellular environment that enables biochemical reactions and enzymes to function at optimum rates; it also plays an important role in sending and receiving cellular signals, and it takes part in the process of nutrient absorption [36]. With this in mind, the reduction 
in spermatic plasma membrane integrity may be directly associated with cellular damage. It is not difficult to conclude that exposure to CuNPs and $\mathrm{Cu}$ ions have different effects on the structure of epididymis, although so far, there are few reports on the damage of copper nanoparticles on the epididymis structure of Chinese soft-shelled turtles.

\subsection{Effect of CuNPs and Cu Ions on the Antioxidant Enzyme Activity}

NPs can cause oxidative damage to the aquatic tissue; they would induce the generation of reactive oxygen species (ROS) and oxidative damage. To lessen the damage, organisms have developed a detoxification system with antioxidant enzyme components, such as SOD, CAT, and GSH, which protect cells against oxidative damage and remove superoxide radicals and hydrogen peroxide [37]. In this study, the antioxidant enzymes activities were determined in the epididymis of Chinese soft-shelled turtles with the treatment of 5 and $50 \mathrm{mg} \mathrm{kg}^{-1} \mathrm{CuNPs}$ and $\mathrm{CuSO}_{4}$. The results showed that the injection of CuNPs and $\mathrm{CuSO}_{4}$ resulted in a massive ROS production, and it increased with the increasing concentration of both $\mathrm{CuNPs}$ and $\mathrm{CuSO}_{4}$ (Figure 3A). The ROS level was not significantly affected by time, except for $50 \mathrm{mg} \mathrm{kg}^{-1} \mathrm{CuSO}_{4}$. ROS decreased at $48 \mathrm{~h}$ and $72 \mathrm{~h}$ compared to $24 \mathrm{~h}$ (Figure 3A). This may be due to the epididymal epithelial necrosis rate, which increased with the treatment of $\mathrm{CuSO}_{4}$ for time. SOD, CAT, and GSH activities significantly increased with the treatment of both $\mathrm{CuNPs}$ and $\mathrm{CuSO}_{4}$ (Figure 3B,C), as the SOD-CAT system is the first line to defend against oxidative stress [38]. Compared to the control, SOD activity even with a low dose $\left(5 \mathrm{mg} \mathrm{kg}^{-1}\right)$ of $\mathrm{CuNPs}$ and $\mathrm{CuSO}_{4}$ significantly increased $(p<0.05)$. It increased by $37.6 \%$ and $197.0 \%$ after $72 \mathrm{~h}$ injection with $5 \mathrm{mg} \mathrm{kg}^{-1} \mathrm{CuNPs}$ and $\mathrm{CuSO}_{4}$, respectively. There was no significant difference of antioxidant enzymes activities at different times, except for the treatment of $50 \mathrm{mg} \mathrm{kg}^{-1} \mathrm{CuSO}_{4}$ (Figure 3). SOD, CAT, and GSH activities in the epididymis of the Chinese soft-shelled turtle with the treatment of $50 \mathrm{mg} \mathrm{kg}^{-1} \mathrm{CuSO}_{4}$ significantly increased; however, they significantly decreased with time. This may be explained by the broken epithelial cells with the treatment of $50 \mathrm{mg} \mathrm{kg}^{-1}$ $\mathrm{CuSO}_{4}$ (Figure 3). The ROS levels and CAT activity decreased significantly at $48 \mathrm{~h}$ and $72 \mathrm{~h}$. Combined with histological results, it can be seen that with time, the epididymal epithelial necrosis rate increased, resulting in a decrease in CAT activity. According to the related literature [39], ROS plays an important role in the process of removing necrotic cells. We speculate that this may be one of the important reasons for the decline in ROS levels. GSH is involved in cell protection by providing reducing capacity through the transformation of reduced to oxidized GSH and binding to metals during the detoxification process [30]. These results showed that the antioxidant capacity was significantly impaired in the epididymis due to massive ROS production, which resulted in oxidative stress. The accumulation of ROS in sperm leads to a reduction in sperm motility, viability, and enzymatic activity [40]. The accumulation of ROS to high concentrations leads to oxidative stress and subsequent lipid peroxidation (LPO), which provokes an irreversible loss of motility and inhibition of fructolysis and respiration in spermatozoa [41]. This could be an explanation of the decrease in sperm motility, viability, and enzymatic activity. In addition, sperm motility is particularly associated with mitochondria activity, as mitochondria represent the cell energy generator and concomitantly the major site of intracellular ROS formation, resulting in a disruption of electron transport. This disruption also participates in the decline of motility and amplifies LPO in the spermatozoa membrane. 

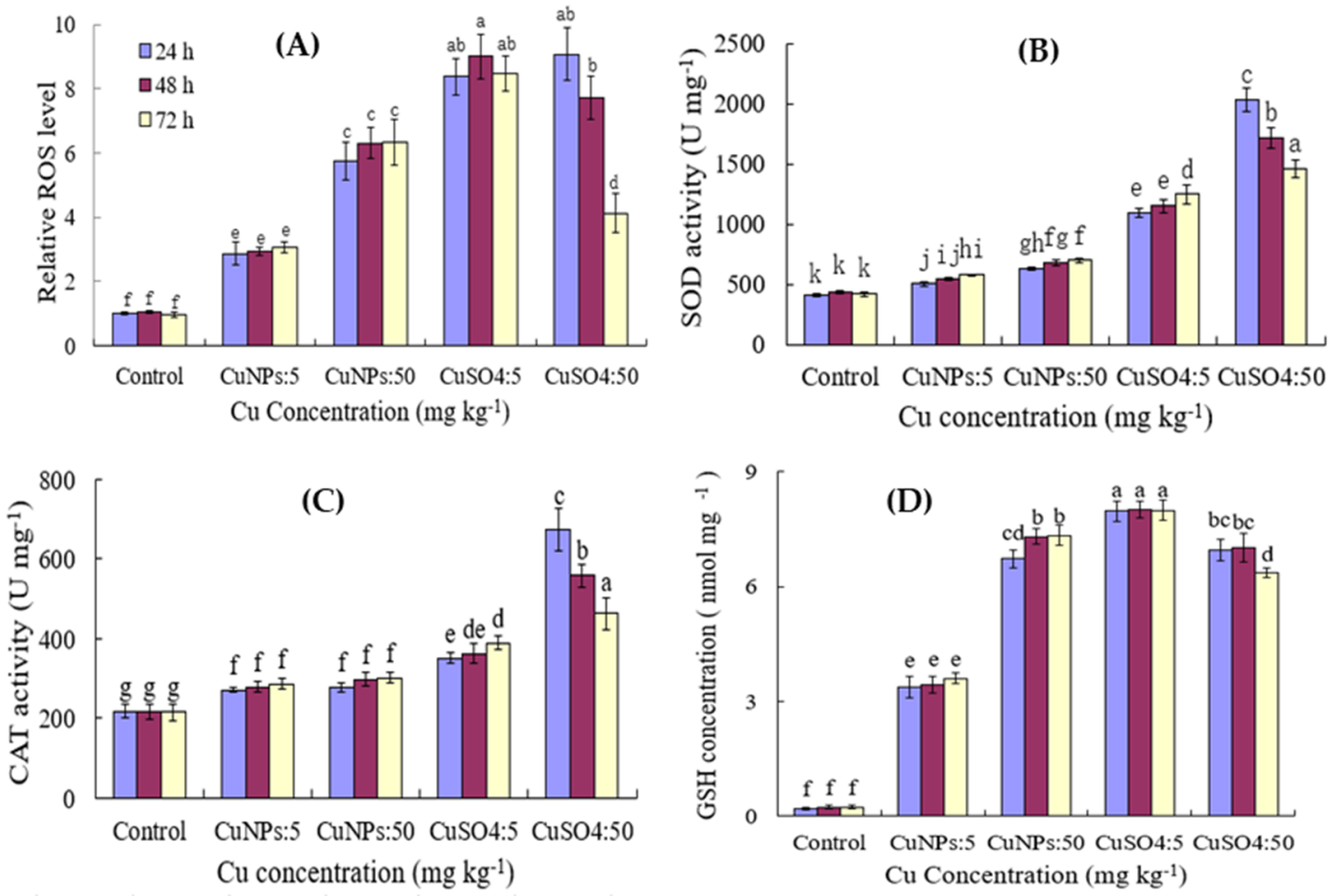

Figure 3. ROS and antioxidant enzyme activities with the treatment of CuNPs and $\mathrm{CuSO}_{4}$. (A-D) represent the level of ROS and the activity of antioxidant enzymes SOD, CAT, and GSH, respectively. Different letters at the top of the histogram indicate significant differences between groups $(p<0.05)$.

\subsection{Effect of $\mathrm{CuNPs}$ and $\mathrm{Cu}$ Ions on the Relative mRNA Expression}

The expression of IL- $1 \beta$, TNF- $\alpha$, and IL- 6 mRNA in the cauda epididymis of the Chinese soft-shelled turtle treated with CuNPs and $\mathrm{CuSO}_{4}$ was detected by qPCR. The mRNA expression of the three inflammatory factors significantly increased with the treatment of CuNPs and $\mathrm{CuSO}_{4}$ (Figure 4). They increased with the increase in the CuNPs concentrations and time (Figure 4). Different from CuNPs treatment, the relative expression of IL-1 $\beta$ and IL- 6 mRNA caused by $5 \mathrm{mg} \mathrm{kg}^{-1} \mathrm{CuSO}_{4}$ treatment increased progressively with time, peaking at $48 \mathrm{~h}$ after injection. However, the injection of $50 \mathrm{mg} \mathrm{kg}^{-1} \mathrm{CuSO}_{4}$ resulted in a significant decrease in the relative expression of IL-1 $\beta$ and IL-6 mRNA with time (Figure 4). IL- $1 \beta$ and TNF $\alpha$ are well-known pro-inflammatory cytokines and are generally considered to be markers to assess the inflammatory response when there is an immune stimulus in vertebrates [41]. Compelling evidence suggests that the two cytokines have similar functions to their mammalian homologues [42,43]. Our results showed that IL-1 $\beta$ and TNF $\alpha$ expression were greatly enhanced after $\mathrm{CuNPs}$ and $\mathrm{CuSO}_{4}$ treatment, which suggests that the inflammatory response to the epididymis of the Chinese soft-shelled turtle significantly increased after the stress of CuNPs and $\mathrm{CuSO}_{4}$. The difference of $\mathrm{CuNPs}$ and $\mathrm{CuSO}_{4}$ in mRNA expression of inflammatory factors may be caused by the amount of soluble ions released from CuNPs being much lower than the concentration of corresponding $\mathrm{CuSO}_{4}$. The cytokine IL-6 possesses pro-inflammatory activity, and it is mainly produced by $\mathrm{T}$ cells and macrophages. In reptiles, there is no report on IL-6 expression after CuNPs treatment. Our results show that CuNPs and $\mathrm{CuSO}_{4}$ treatment can also cause significant expression of the inflammatory factor IL-6 (Figure 4), but the underlying mechanism needs to be further studied. 
(A)
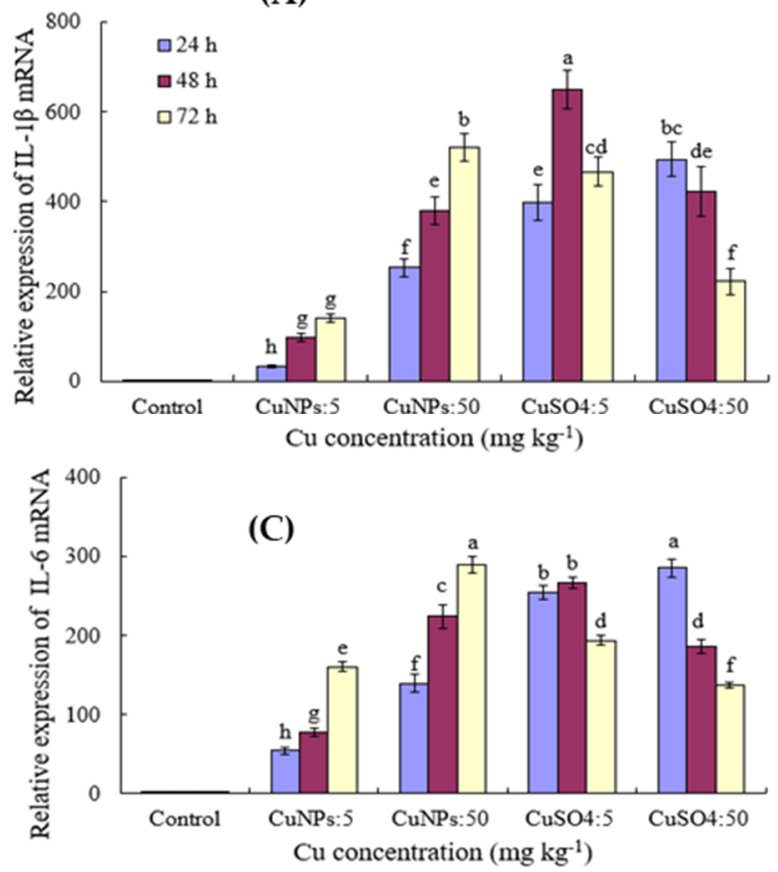

(B)

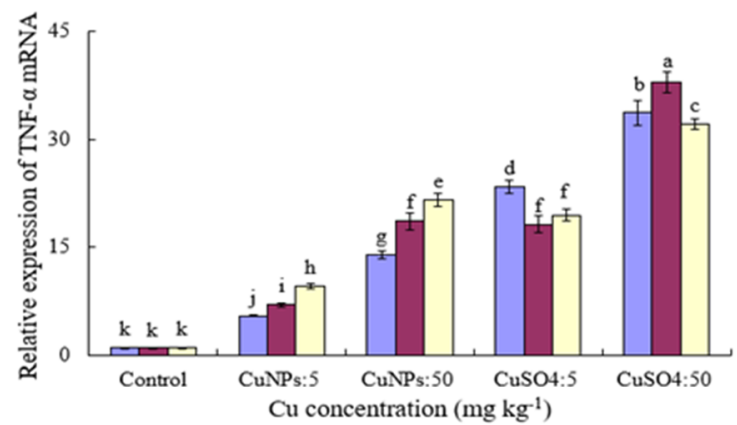

Figure 4. The relative inflammatory factors mRNA expression with the treatment of CuNPs and $\mathrm{CuSO}_{4}$. (A-C) represent the relative expression levels of IL-1 $\beta, T N F \alpha$, and IL-6 mRNA, respectively. Different letters at the top of the histogram indicate significant differences between groups $(p<0.05)$.

\section{Conclusions}

This study showed that $\mathrm{Cu}$ ions exert a more harmful effect on the epididymis and spermatozoa viability of Chinese soft-shelled turtles than copper nanoparticles. Contamination of the aqueous environment with copper primarily caused a reduction in sperm viability, which may impair reproduction. The antioxidative enzymes and the relative inflammatory factors (IL-1 $\beta, T N F \alpha$, and IL-6 mRNA) expression in the epididymis of Chinese soft-shelled turtles significantly increased with the treatment of $\mathrm{CuNPs}$ and $\mathrm{CuSO}_{4}$. The exposure to $\mathrm{CuSO}_{4}$ caused obvious morphological damage to the epididymis of Chinese soft-shelled turtles, such as, the epithelium of the epididymal tube peeled off. These findings in this work may provide preliminary information regarding the ecological impacts of CuNPs on the fertilization efficiency of aquatic organisms.

Supplementary Materials: The following supporting information can be downloaded at: https: / / www.mdpi.com/article/10.3390/coatings12020110/s1, Figure S1: Representative TEM image (A) and particle size distribution (B) of CuNPs in Milli-Q water.

Author Contributions: L.Y. Conceptualization, Methodology, Writing-Original draft preparation; Y.W. Software; S.G. Data curation; Q.W. Investigation; J.C. Validation; B.T. Resources; X.B. Editing, Visualization. All authors have read and agreed to the published version of the manuscript.

Funding: This research was funded by the sponsorship of Jiangsu overseas visiting scholar program for university prominent young and middle-aged teachers and presidents and the natural science foundation of the Jiangsu higher education institutions of China (20KJA180006), innovation and entrepreneurship training program for college students in Jiangsu Province (202110324018Z), (202110324022Y), and foundation of Jiangsu Key Laboratory for Bioresources of Saline Soils (JKLBS2021007).

Institutional Review Board Statement: Not applicable.

Informed Consent Statement: Not applicable.

Data Availability Statement: Data are contained within the article or Supplementary Materials.

Conflicts of Interest: The authors declare no conflict of interest. 


\section{References}

1. Hou, J.; Wang, X.X.; Hayat, T.; Wang, X.K. Ecotoxicological effects and mechanism of CuO nanoparticles to individual organisms. Environ. Pollut. 2017, 221, 209-217. [CrossRef] [PubMed]

2. Yang, L.; Wang, W.X. Comparative contributions of copper nanoparticles and ions to copper bioaccumulation and toxicity in barnacle larvae. Environ. Pollut. 2019, 249, 116-124. [CrossRef]

3. Adeleye, A.S.; Oranu, E.A.; Tao, M.; Keller, A.A. Release and detection of nanosized copper from a commercial antifouling paint. Water Res. 2016, 102, 374-382. [CrossRef] [PubMed]

4. Muller-Karanassos, C.; Arundel, W.; Lindeque, P.K.; Vance, T.; Turner, A.; Cole, M. Environmental concentrations of antifouling paint particles are toxic to sediment dwelling invertebrates. Environ. Pollut. 2020, 268, 115754. [CrossRef]

5. Wu, F.; Harper, B.J.; Crandon, L.E.; Harper, S.L. Assessment of $\mathrm{cu}$ and $\mathrm{CuO}$ nanoparticle ecological responses using laboratory small-scale microcosms. Environ. Sci. Nano 2020, 7, 105-115. [CrossRef]

6. Bashir, I.; Lone, F.A.; Bhat, R.A.; Mir, S.A.; Dar, Z.A.; Dar, S.A. Concerns and threats of contamination on aquatic ecosystems. In Bioremediation and Biotechnology; Springer: Cham, Switzerland, 2020; pp. 1-26.

7. Zhu, Y.C.; Xu, J.H.; Lu, T.; Zhang, M.; Ke, M.J.; Fu, Z.W.; Pan, X.L.; Qian, H.F. A comparison of the effects of Cu nanoparticles and $\mathrm{Cu}$ sulfate on Phaeodactylum tricornutum physiology and transcription. Environ. Toxicol. Pharmacol. 2017, 56, 43-49. [CrossRef] [PubMed]

8. $\quad$ Fang, R.; Gong, J.L.; Cao, W.C.; Chen, Z.P.; Huang, D.L.; Ye, J.; Cai, Z. The combined toxicity and mechanism of multi-walled carbon nanotubes and nano copper oxide toward freshwater algae: Tetradesmus obliquus. J. Environ. Sci. 2022, 112, 376-387. [CrossRef] [PubMed]

9. Zhang, C.; Li, F.; Xiang, J. Acute effects of cadmium and copper on survival, oxygen consumption, ammonia-N excretion, and metal accumulation in juvenile Exopalaemon carinicauda. Ecotoxicol. Environ. Saf. 2014, 104, 209-214. [CrossRef]

10. Bat, L.; Gündoğdu, A.; Sezgin, M.; Çulha, M.; Gönlügür, G.; Akbulut, M. Acute toxicity of zinc, copper and lead to three species of marine organisms from the Sinop Peninsula, Black Sea. Turk. J. Biol. 1999, 23, 537-544.

11. Vardhanan, Y.S.; Radhakrishnan, T. Acute toxicity evaluation of copper, arsenic and HCH to paddy field crab, Paratelphusa hydrodromus (Herb). J. Environ. Biol. 2002, 23, 387-392. [PubMed]

12. Chourpagar, A.R.; Kulkarni, G.K. Heavy metal toxicity to a freshwater crab, Barytelphusa cunicularis (westwood) from aurangabad region. Recent Res. Sci. Technol. 2011, 3, 1-5.

13. Bini, G.; Chelazzi, G. Acclimatable cardiac and ventilatory responses to copper in the freshwater crayfish Procambarus clarkii. Comp. Biochem. Physiol. C Toxicol. Pharmacol. 2006, 144, 235-241. [CrossRef]

14. Malhotra, N.; Ger, T.R.; Uapipatanakul, B.; Huang, J.C.; Chen, K.H.; Hsiao, C.D. Review of Copper and Copper Nanoparticle Toxicity in Fish. Nanomaterials 2020, 10, 1126. [CrossRef] [PubMed]

15. Boyle, D.; Clark, N.J.; Handy, R.D. Toxicities of copper oxide nanomaterial and copper sulphate in early life stage zebrafish: Effects of $\mathrm{pH}$ and intermittent pulse exposure. Ecotoxicol. Environ. Saf. 2020, 190, 109985. [CrossRef]

16. Adam, N.; Schmitt, C.; De Bruyn, L.; Knapen, D.; Blust, R. Aquatic acute species sensitivity distributions of ZnO and CuO nanoparticles. Sci. Total Environ. 2015, 526, 233-242. [CrossRef]

17. Jiang, C.J.; Castellon, B.T.; Matson, C.W.; Aiken, G.R.; Hsu-Kim, H. Relative contributions of Cu oxide nanoparticles and dissolved $\mathrm{Cu}$ to $\mathrm{Cu}$ uptake kinetics of gulf killifish (Fundulus grandis) embryos. Environ. Sci. Technol. 2017, 51, 1395-1404. [CrossRef] [PubMed]

18. Hua, J.; Vijver, M.G.; Richardson, M.K.; Ahmad, F.; Peijnenburg, W.J. Particlespecific toxic effects of differently shaped zinc oxide nanoparticles to zebrafish embryos (Danio rerio). Environ. Toxicol. Chem. 2014, 33, 2859-2868. [CrossRef] [PubMed]

19. Wang, N.; Liu, D.; Xie, M.W.; Li, Q.B.; Liu, Q.M. Behavior and toxicity of zinc oxide nanoparticles in aquatic environment. Environ. Chem. 2016, 35, 2528-2534.

20. Volland, M.; Hampel, M.; Katsumiti, A.; Yeste, M.P.; Gatica, J.M.; Cajaraville, M.; Blasco, J. Synthesis methods influence characteristics, behaviour and toxicity of bare $\mathrm{CuO}$ NPs compared to bulk $\mathrm{CuO}$ and ionic $\mathrm{Cu}$ after in vitro exposure of Ruditapes philippinarum hemocytes. Aquat. Toxicol. 2018, 199, 285-295. [CrossRef] [PubMed]

21. Zhang, Y.J.; Ding, Z.C.; Zhao, G.; Zhang, T.; Xu, Q.H.; Cui, B.; Liu, J.X. Transcriptional responses and mechanisms of Cu nanoparticle toxicology on zebrafish embryos. J. Hazard Mater. 2018, 344, 1057-1068. [CrossRef]

22. Lopes, F.M.; Varela Junior, A.S.; Corcini, C.D.; Da Silva, A.C.; Guazzelli, V.G.; Tavares, G.; Da Rosa, C.E. Effect of glyphosate on the sperm quality of zebrafish Danio rerio. Aquat. Toxicol. 2014, 155, 322-326. [CrossRef] [PubMed]

23. Devaux, A.; Bony, S.; Plenet, S.; Sagnes, P.; Segura, S.; Suaire, R.; Novack, M.; Gilles, A.; Olivier, J.M. Field evidence of reproduction impairment through sperm DNA damage in the fish nase (Chondrostoma nasus) in anthropized hydrosystems. Aquat. Toxicol. 2015, 169, 113-122. [CrossRef] [PubMed]

24. Kowalska-Góralska, M.; Dziewulsk, K.; Kulasz, M. Effect of copper nanoparticles and ions on spermatozoa motility of sea trout (Salmo trutta m. Trutta L.). Aquat. Toxicol. 2019, 211, 11-17. [CrossRef] [PubMed]

25. Mansouri, B.; Maleki, A.; Johari, S.A.; Shahmoradi, B.; Mohammadi, E.; Davari, B. Histopathological effects of copper oxide nanoparticles on the gill and intestine of common carp (Cyprinus carpio) in the presence of titanium dioxide nanoparticles. Chem. Ecol. 2017, 33, 295-308. [CrossRef]

26. Gürkan, M.; Gürkan, S.E.; Yılmaz, S.; Ate, M. Comparative toxicity of Alpha and Gamma iron oxide nanoparticles in Rainbow Trout: Histopathology, hematology, accumulation, and oxidative stress. Water Air Soil Pollut. 2021, 232, 37-52. [CrossRef] 
27. Kim, E.H.; Jeong, J.A.; Choi, E.K.; Jeong, T.Y. Antioxidant enzyme activity in Daphnia magna under microscopic observation and shed carapace length as an alternative growth endpoint. Sci. Total Environ. 2021, 794, 148771. [CrossRef]

28. Chen, B.J.; Zhang, W.Y.; Niu, C.J.; Li, W.J.; Jia, H.; Storey, K.B. Antioxidant response to acute cold exposure and during recovery in juvenile Chinese soft-shelled turtles (Pelodiscus sinensis). J. Exp. Biol. 2019, 222, 197863. [CrossRef]

29. Sanpradit, P.; Buapet, P.; Kongseng, S.; Peerakietkhajorn, S. Temperature and concentration of ZnO particles affect life history traits and oxidative stress in Daphnia magna. Aquat. Toxicol. 2020, 224, 105517. [CrossRef]

30. Zhang, W.J.; Gao, J.L.; Lu, L.; Bold, T.; Li, X.; Wang, S.; Chang, Z.S.; Chen, J.; Kong, X.; Zheng, Y.X.; et al. Intracellular GSH/GST antioxidants system change as an earlier biomarker for toxicity evaluation of iron oxide nanoparticles. NanoImpact 2021, 23, 100338. [CrossRef]

31. Zarski, D.; Cejko, B.I.; Krejszeff, S.; Palinska-Zarska, K.; Horvath, A.; Sarosiek, B.; Judycka, S.; Kowalski, R.K.; Laczynska, B.; Kucharczyk, D. The effect of osmolality on egg fertilization in common carp, Cyprinus carpio Linnaeus, 1758. J. Appl. Ichthyol. 2015, 31, 159-163. [CrossRef]

32. Bian, X.G.; Gandahi, J.A.; Liu, Y.; Yang, P.; Liu, Y.; Zhang, L.L.; Zhang, Q.; Chen, Q.S. The ultrastructural characteristics of the spermatozoa stored in the cauda epididymidis in Chinese soft-shelled turtle Pelodiscus sinensis during the breeding season. Micron 2013, 44, 202-209. [CrossRef]

33. Zebral, Y.D.; Anni, I.S.A.; Junior, A.S.V.; Corcini, C.D.; Silva, J.C.; Caldas, J.S.; Acosta, I.B.; Afonso, S.B.; Bianchini, A. Life-time exposure to waterborne copper IV: Sperm quality parameters are negatively affected in the killifish Poecilia vivipara. Chemosphere 2019, 236, 124332. [CrossRef] [PubMed]

34. Sakhaee, E.; Emadi, L.; Abshenas, J.; Kheirandish, R.; Azari, O.; Amiri, E. Evaluation of epididymal sperm quality following experimentally induced copper poisoning in male rats. Andrologia 2012, 44, 110-116. [CrossRef] [PubMed]

35. Roychoudhury, S.; Massanyi, P. In vitro copper inhibition of the rabbit spermatozoa motility. J. Environ. Sci. Health Part A 2008, 43, 651-656. [CrossRef]

36. Zhang, Y.; Chen, X.; Gueydan, C.; Han, J. Plasma membrane changes during programmed cell deaths. Cell Res. 2018, $28,9$. [CrossRef]

37. Yuan, J.L.; Gu, Z.M.; Zheng, Y.; Zhang, Y.Y.; Gao, J.G.; Chen, S.; Wang, Z.Z. Accumulation and detoxification dynamics of microcystin-LR and antioxidant responses in male red swamp crayfish Procambarus clarkii. Aquat. Toxicol. 2016, 177, 8-18. [CrossRef]

38. Mahmoud, A.E.; Mahmoud, M.A.D.; Amaal, M.; Radwa, M.S. Effects of titanium dioxide nanoparticles on red swamp crayfish, Procambarus clarkii: Bioaccumulation, oxidative stress and histopathological biomarkers. Egypt. J. Aquat. Res. 2019, 45, 11-18.

39. Bagaitkar, J.; Huang, J.; Zeng, M.Y.; Pech, N.K.; Monlish, D.A.; Perez-Zapata, L.J.; Miralda, I.; Schuettpelz, L.G.; Dinauer, M.C. NADPH oxidase activation regulates apoptotic neutrophil clearance by murine macrophages. Blood 2018, 131, 2367-2378. [CrossRef]

40. Mostek, A.; Słowińska, M.; Judycka, S.; Karol, H.; Ciereszko, A.; Dietrich, M.A. Identification of oxidatively modified proteins due to cryopreservation of carp semen. J. Anim. Sci. 2018, 96, 1453-1465. [CrossRef]

41. Varfolomeev, E.E.; Ashkenazi, A. Tumor Necrosis Factor. Cell 2004, 116, 491-497. [CrossRef]

42. Reis, M.I.R.; Vale, A.D.; Pereira, P.J.B.; Azevedo, J.E.; dos Santo, N.M.S. Caspase-1 and IL-1 $\beta$ Processing in a Teleost Fish. PLoS ONE 2012, 7, 50450 .

43. Zhang, A.; Chen, D.; Wei, H.; Du, L.; Zhao, T.; Wang, X.; Hong, Z. Functional characterization of TNF- $\alpha$ in grass carp head kidney leukocytes: Induction and involvement in the regulation of NF-kB signaling. Fish Shellfish Immun. 2012, 33, 1123-1132. [CrossRef] 